\title{
Relationship between mineral and protein deposition in restricted and realimented pigs
}

\author{
D. Weremko ${ }^{1}$, H. Fandrejewski, St. Raj, G. Skiba and M. Czauderna \\ The Kielanowski Institute of Animal Physiology and Nutrition, Polish Academy of Sciences \\ 05-110 Jabłonna, Poland
}

\begin{abstract}
Mineral retention and its relation to protein deposition was measured in 54 crossbreed pigs allocated to a control and two restricted (up to 50 or $80 \mathrm{~kg} \mathrm{BW}$ ) groups. Control pigs were continuously fed a basal diet (B) and restricted pigs, diet B mixed with $20 \%$ grass meal. During re-alimentation, previously restricted pigs were fed diet B up to $105 \mathrm{~kg}$. The animals were slaughtered at 25, 50, 80 and $105 \mathrm{~kg} \mathrm{BW}$. The previously restricted pigs showed a compensatory response with regard to protein as well as $\mathrm{P}, \mathrm{Ca}$ and $\mathrm{Mg}$ deposition. The reaction in both protein and minerals depended on the duration of previous restriction and was full only in the pigs restricted to $50 \mathrm{~kg} \mathrm{BW}$. According to an allometric equation, the mineral content increased faster ("b">1) than protein. Compensatory mineral gains in the body were closely related to protein gain and the daily mineral/protein deposition ratio was the same in all treatments.
\end{abstract}

KEY WORDS: protein, minerals, pigs

\section{INTRODUCTION}

A positive correlation between protein and mineral deposition in the pig body has been documented (Rymarz et al., 1982; Mahan and Shields, 1998). It is also known that in temporarily restricted pigs, protein deposition is decreased, but during subsequent realimentation, it is enhanced. However, information on mineral deposition in sotreated pigs is lacking. Thus, the aim of the study was to assess mineral deposition in pigs in relation to protein accretion during restriction and realimentation.

\section{MATERIAL AND METHODS}

Fifty-four crossbreed pigs from 25 to $105 \mathrm{~kg}$ body weight were kept individually and fed ad libitum. Two diets, basal (B) and high-fibre (F) were used.

\footnotetext{
${ }^{1}$ Corresponding author: e-mail: d.weremko@ifzz.pan.pl
} 
Diet B contained 13.1 MJ EM and $8.9 \mathrm{~g}$ digestible lysine, $5.29 \mathrm{~g}$ total phosphorus, $6.7 \mathrm{~g}$ calcium (with Ca:P ratio of 1.3:1), and $119 \mathrm{~g}$ zinc. Diet $\mathrm{F}$ was a mixture of diet B (80\%) and grass meal (20\%) and contained less energy, digestible lysine, total and digestible phosphorus, calcium and zinc by $12,17,8,11,7$ and $8 \%$, respectively. Control pigs were continuously fed the basal diet. The $\mathrm{F}_{50}$ and $\mathrm{F}_{80}$ pigs were restricted by feeding them diet $\mathrm{F}$ up to 50 or $80 \mathrm{~kg}$, respectively. During realimentation, all previously restricted pigs were fed diet B up to $105 \mathrm{~kg}$. The animals were slaughtered at $25(n=6), 50(n=12 ; 6$ each from groups $B$ and F), $80\left(n=18 ; 6\right.$ each from groups $B, F$, and $\left.F_{50}\right)$ and $105 \mathrm{~kg}(n=18 ; 6$ each from groups $\mathrm{B}_{50}$ and $\mathrm{F}_{80}$ ). The protein content was determined according to standard methods (AOAC, 1990), P spectrophotometrically using molybdovanadate as the colour-forming reagent, $\mathrm{Ca}$ and $\mathrm{Zn}$ from ash solutions by atomic absorption spectrophotometry. Protein and mineral retention in the body were calculated from the difference between their final and initial contents in a particular growth stage using the comparative slaughter technique.

\section{RESULTS AND DISCUSSION}

At $25 \mathrm{~kg}$ the body of pigs contained $4.0 \mathrm{~kg}$ of protein, $580 \mathrm{~g}$ of ash and 115 , $196,6.58$ and $0.41 \mathrm{~g}$ of $\mathrm{P}, \mathrm{Ca}, \mathrm{Mg}$ and $\mathrm{Zn}$, respectively. The content of these components increased with growth and, in pigs fed on diet B up to $105 \mathrm{~kg}$ liveweight, reached levels of $15.2 \mathrm{~kg}$ of protein, $2.6 \mathrm{~kg}$ ash of ash and 485, 850, 28 and 1.9 $\mathrm{g}$ of $\mathrm{P}, \mathrm{Ca}, \mathrm{Mg}$ and $\mathrm{Zn}$, respectively; these values are similar to those reported by Kirchgessner et al. (1994).

During restriction up to $50 \mathrm{~kg}$ (group $\mathrm{F}_{50}$ ), pigs deposited daily $24 \mathrm{~g}$ less protein $(\mathrm{P}<0.05)$ as compared with the $\mathrm{B}$ pigs. This was associated with a significant decrease of ash and P deposition (16.8 vs 20.6 and 2.5 vs $3.4 \mathrm{~g} /$ day, respectively). Retention of the remaining minerals was also less in restricted pigs: by $0.9 \mathrm{~g}$ of $\mathrm{Ca}, 38 \mathrm{mg}$ of $\mathrm{Mg}$ and $2.1 \mathrm{mg} \mathrm{Zn} \mathrm{(differences} \mathrm{nonsignificant).}$

Pigs restricted from 25 to $80 \mathrm{~kg}\left(\mathrm{~F}_{80}\right)$ reduced protein and phosphorus deposition by 9 and $0.4 \mathrm{~g}$, and zinc retention by $2.7 \mathrm{mg}$, but the deposition of other minerals during this time was similar. However, at $80 \mathrm{~kg}$ they were 6 days older than their analogues from the control group. In this growth period, pigs re-alimented from $50 \mathrm{~kg}\left(\mathrm{~F}_{50}\right)$ increased daily protein deposition by $19 \mathrm{~g}(\mathrm{P}<0.01)$ and $\mathrm{P}$ retention by $0.5 \mathrm{~g}(\mathrm{P}<0.01)$ more than restricted animals. The $\mathrm{F}_{80}$ and $\mathrm{F}_{50}$ pigs also deposited more $\mathrm{Ca}$.

When the total growth period $(25-105 \mathrm{~kg})$ was considered, pigs from the basal group and those realimented from $50 \mathrm{~kg}$ deposited similar amounts of protein, ash, $\mathrm{P}, \mathrm{Ca}$ and $\mathrm{Mg}$. However, in pigs realimented from $80 \mathrm{~kg}$, deposition of body 
components was lower than in control animals, which may indicate that compensation in this group was not complete. Therefore, a certain compensatory response could be expected during subsequent growth, which was examined by an allometric model with protein content in the body as the independent variable. In calculations, 3 different paths of growth: control and two restricted/realimentd were separated. Table 2 shows that " $b$ " (growth coefficient) is generally higher (by $3-6 \%$ ) in pigs from group $\mathrm{F}_{50}$ than in controls, except $\mathrm{Ca}$, which indicates that compensatory retention of minerals takes place. In $\mathrm{F}_{80}$ pigs, the growth coefficients were on similar levels or slightly lower as compared with control pigs, indicating that restriction prolonged up to $80 \mathrm{~kg}$ was too severe and the animals could not compensate deposition of body components. This suggests that the intensity of the compensatory response with regard to mineral retention depends on the duration of previous restriction.

Table 2. Relationship between protein (in $\mathrm{kg}$ ) and mineral (Y) content in the body during growth of pigs from 25 to $105 \mathrm{~kg}$ as expressed by the formula: $\mathrm{Y}=\mathrm{a}^{*}$ protein $^{\mathrm{b}}$

\begin{tabular}{llccc}
\hline Minerals & Group of pigs & $\mathrm{a}$ & $\mathrm{b}$ & $\mathrm{R}^{2}$ \\
\hline \multirow{3}{*}{$\mathrm{P}, \mathrm{g}$} & Basal (B) & $19.3 \pm 4.06$ & $1.175 \pm 0.08$ & 98.1 \\
& ${\text { Compensatory } \mathrm{F}_{50}}$ & $17.0 \pm 3.55$ & $1.213 \pm 0.08$ & 98.2 \\
& ${\text { Compensatory } \mathrm{F}_{80}}$ & $18.9 \pm 8.45$ & $1.164 \pm 0.17$ & 98.2 \\
$\mathrm{Ca}, \mathrm{g}$ & & & \\
& Basal (B) & $38.8 \pm 6.97$ & $1.134 \pm 0.07$ & 98.2 \\
& ${\text { Compensatory } \mathrm{F}_{50}}$ & $40.8 \pm 7.88$ & $1.117 \pm 0.08$ & 97.9 \\
& Compensatory $\mathrm{F}_{80}$ & $52.1 \pm 7.60$ & $1.013 \pm 0.06$ & 98.5 \\
$\mathrm{Mg}, \mathrm{g}$ & & & \\
& Basal (B) & $1.7 \pm 0.41$ & $1.025 \pm 0.09$ & 95.9 \\
& Compensatory $\mathrm{F}_{50}$ & $1.6 \pm 0.26$ & $1.052 \pm 0.06$ & 98.2 \\
& Compensatory $\mathrm{F}_{80}$ & $2.1 \pm 0.49$ & $0.944 \pm 0.09$ & 94.8 \\
& & & & \\
$\mathrm{Zn}, \mathrm{mg}$ & Basal (B) & $76.9 \pm 14.82$ & $1.167 \pm 0.07$ & 98.7 \\
& Compensatory $\mathrm{F}_{50}$ & $62.5 \pm 18.80$ & $1.237 \pm 012$ & 96.7 \\
& Compensatory $\mathrm{F}_{80}$ & $72.9 \pm 12.24$ & $1.181 \pm 0.07$ & 98.6 \\
\hline
\end{tabular}

The values of growth coefficients also indicate that the amount of deposited minerals increased at a faster rate ("b">1) than the amount of protein, which is in agreement with earlier results reported by Rymarz et al. (1982). Correlation between the mineral and protein content in the body was high and ranged from 94.8 for $\mathrm{Mg}$ to 98.7 for $\mathrm{Zn}$. This confirms earlier findings that accretion of protein and minerals is closely connected, and the ratio of daily mineral/protein deposition was the same for all treatments in the investigated growth period. This ratio was the highest for $\mathrm{Ca}$ /protein (average 0.060 ), lowest for $\mathrm{Zn} /$ protein (average 0.00012 ) and rose with increasing body weight of pigs. 


\section{CONCLUSIONS}

Pigs with temporarily restricted growth showed a compensatory response with regard to protein as well as $\mathrm{P}, \mathrm{Ca}$ and $\mathrm{Mg}$ deposition. This response in both protein and minerals depended on the duration of previous restriction and was full only in those pigs that were restricted up to $50 \mathrm{~kg}$ body weight. Compensatory mineral gains in the body were closely related to protein gain. The daily mineral/protein deposition ratio was the same in all groups.

\section{REFERENCES}

AOAC, 1995. Official Methods of Analysis, Association of Official Analytical Chemists. $16^{\text {th }}$ Edition. Arlington, VA

Kirchgessner M., Kreuzer M., Roth F.X., 1994. Alters- und Geschlechtsbedinge unterschiede in den Gehalten an $\mathrm{Fe}, \mathrm{Zn}, \mathrm{Cu}$ und $\mathrm{Mn}$ verschiedener Korperpartien sowie ihre Retention bei Mastschweinen. Arch. Anim. Nutr. 46, 327-337

Mahan D.C., Shields Jr. R.G., 1998. Macro- and micromineral composition of pigs from birth to 145 kilograms of body weight. J. Anim. Sci. 76, 506-512

Rymarz A., Fandrejewski H., Kielanowski J., 1982. Content and retention of calcium, phosphorus, potassium and sodium in the bodies of growing gilts. Livest. Prod. Sci. 9, 399-407

\section{STRESZCZENIE}

\section{Zależności między odkładaniem białka i składników mineralnych u świń żywionych w sposób ograniczony i podczas realimentacji}

Zależności między odkładaniem białka i składników mineralnych określono na 54 świniach podzielonych na grupę kontrolną i dwie grupy żywione restrykcyjnie (do 50 lub $80 \mathrm{~kg}$ m.c.). Świnie z grupy kontrolnej były żywione dieta standardową (B), z grup restrykcyjnych dietą B z $20 \%$ dodatkiem suszu z traw. Podczas realimentacji świnie z obydwóch grup restrykcyjnych otrzymywały dietę B. Zwierzęta ubito przy masie ciała 25, 50, 80 i $105 \mathrm{~kg}$. U świń żywionych restrykcyjnie stwierdzono reakcję kompensacyjną w odkładaniu białka oraz P, Ca i Mg. Kompensacja zależała od długości okresu restrykcji i była pełna tylko u świń żywionych restrykcyjnie do m.c. $50 \mathrm{~kg}$. Allometryczne równania wykazały, że zawartość składników mineralnych w ciele wzrasta szybciej (,b”>1) niż zawartość białka. Kompensacyjny przyrost składników mineralnych w ciele był ściśle zależny od przyrostu białka, a proporcja dziennego odłożenia składników mineralnych do białka była taka sama w badanych grupach. 